\title{
Ettevõtlustüübid ja rahvusvahelistumine ettevõtlusõppes
}

\author{
Tiit Elenurm ${ }^{\text {a1 }}$ \\ ${ }^{a}$ Estonian Business Schooli juhtimise õppetool
}

\begin{abstract}
Annotatsioon
Ettevõtlusõpet on vaja kohandada eri sihtrühmadele: neile, kes on juba loonud ettevõtte, asuvad õppeprotsessis ettevõtet looma, kavatsevad vahetult peale õpinguid ettevõtte luua või võivad enda ettevõtluspädevust rakendada kaugemas tulevikus. Artikli eesmärk on ettevõtluse olemuse tõlgendustest ja ettevõtlustüüpide võrdlusest lähtudes ning Eesti ettevõtluse rahvusvahelistumise perspektiive arvestades pakkuda välja ettevôtlustüüpide liigitus, mis hõlmaks eri sihtrühmade õpivajadusi ja õpitulemuste rakendamise võimalusi eeskätt kõrghariduses. Ettevõtlusõppe kohandamisel sihtrühmade vajaduste järgi tuleb arvestada ettevõtluse rahvusvahelistumise võimalusi, innovaatilisusest ja kasvuambitsioonist lähtuvaid piiriülese võrgustumise vajadusi, iseseisva ja organisatsioonisisese ettevõtluse konteksti, ettevõtlustüübist sõltuvat ressursibaasi ning individuaalset ja koosloovat ettevõtlusorientatsiooni. Niisama tähtis on õppija kui potentsiaalse või juba tegutseva ettevõtja arengurada, tema valmisolek tegevuse kaudu õppida ja avatud e-õppes osaleda.
\end{abstract}

Võtmesõnad: ettevõtlusõpe, ettevõtlustüübid, rahvusvahelistumine, innovatsioon, võrgustumine

\section{Sissejuhatus}

Eesti ettevõtluse kasvustrateegias aastateks $2014-2020$ on seatud ettevõtluse arendamise üldiseks eesmärgiks suurendada Eesti majanduses hõivatud töötajate tootlikkust 80\%-ni Euroopa Liidu keskmisest. Alaeesmärkidena on nimetatud Eesti elanike ettevõtlikkuse ja ettevõtete ambitsioonikuse suurendamist, suure lisandväärtusega toodete ja teenuste efektiivset tootmist, aktiivset eksporti ja Eesti ettevõtluskeskkonna konkurentsivõimelisust. Ettevõtluse kasvu-

Estonian Business School, A. Lauteri 3, 10114 Tallinn; tiit.elenurm@ebs.ee 
strateegias peetakse vajalikuks tihendada ülikoolide koostööd ettevõtetega, kes saavad ekspordist suurt müügitulu ning kellest sõltub seega Eesti majanduses loodava lisandväärtuse ja tootlikkuse kasv (Majandus- ja Kommunikatsiooniministeerium, 2013). Ettevõtlusõppe oluliste sihtrühmade määramisel ja nende õpivajaduste arvestamisel tuleb silmas pidada, et strateegias seatakse ettevõtluse arendamise fookusesse alustavad ja kiirelt kasvavad ambitsioonikad ettevõtted, kuid rõhutatakse ka vajadust soodustada piirkondlike ettevõtjate arengut, sest need moodustavad oma arvukuses valdava osa Eesti ettevõtjatest. Ettevõtlusõppe jaoks tähendab see elukestva õppe põhimõttest lähtudes vajadust kaasata ettevõtlusesse juba tegutsevaid ettevõtjaid ja noori potentsiaalseid ettevõtjaid ning edendada nende koostööd, võttes arvesse eri õpivajadusi. Ettevõtluse kandepinna laiendamiseks on vaja arvestada ka nende õppijate vajadusi ja lähtesituatsiooni, kes ei ole saanud veel selgust, kas nad on ettevõtlusega tegelemisest huvitatud ja milline võiks olla nende arengurada ettevõtjana.

Artikli eesmärk on leida vastus Eesti kui väikese avatud majanduse jaoks olulisele küsimusele: millisel alusel tuleks kohandada ettevõtlusõpet eri ettevõtlustüüpe esindavatele sihtrühmadele ettevõtluse rahvusvahelistumise kontekstis? Esmalt esitatakse artiklis ülevaade ettevõtluse olemuse ja arendusprioriteetide tõlgendustest varasemates ettevõtlusuurimustes, mis pakuvad alusteavet eri sihtrühmade vajaduste arvestamiseks ettevõtlusõppes. Seejärel iseloomustatakse ettevõtlustüüpe, pidades silmas vajadust diferentseerida ettevõtlusõpet üksikettevõtja või ettevõtlustiimi lähtesituatsiooni, eesmärkide või arenguraja alusel. Eraldi käsitletakse ettevõtlusõppe rolli Eesti ettevõtluse rahvusvahelistumise toetamisel, milleks tuleb ühelt poolt arvestada ambitsioonika kasvuettevõtluse eripära, teisalt leida piiriüleseid rakendusvõimalusi. Artikli teises pooles selgitatakse ettevõtlusõppe diferentseerimise prioriteete, tuginedes Eesti Majandusteaduste Seltsi aastakonverentsil toimunud rühmaarutelu tulemustele, ja tuuakse näiteid õppemeetodite kohta, mis aitavad ettevõtlusõpet seostada noorte ettevalmistamisega rahvusvaheliseks ettevõtluseks. Seejuures ei püüta esitleda ettevõtlusõppe diferentseerimise terviklikku süsteemi, vaid algatada toodavate näidete kaudu edasisi tegevusuuringuid ja arutelusid.

\section{Ettevõtluse olemuse tõlgendused}

Ettevõtlusõppe arendamise poliitikast eri arengutasemega riikides ilmneb, et ühiskonna tasandil võivad ettevõtluse arendamise ja ettevõtlusõppe prioriteedid olla teadmuspõhist lisaväärtust loovate iduettevõtete (start-up) innovaatiline ettevõtlus, ettevõtluse sotsiaalne suunitlus või tootlikkus ja kulutõhusus, mida on lihtsam saavutada suurtes organisatsioonides (O'Connor, 
2013). Ettevõtlusuuringute kaudu püütakse üha sügavamalt mõista ettevõtjate tegevuse konteksti ja selle mõju ettevõtjate pädevustele, mis on vajalikud edu saavutamiseks (Welter, 2011). Zahra, Wright ja Abdelgawad (2014) rõhutavad ka vajadust arvestada ettevõtluse uurimisel ja ettevõtjate arendamisel tegevusharu ja turu, ettevõtluse ajaliste, sotsiaalsete, ruumiliste ja organisatsiooniliste tunnuste ning omandisuhete konteksti. Ettevõtlusõppe arendamisel tuleb arvesse võtta iseseisva ja organisatsioonisisese ettevõtluse mitmekesiseid võimalusi ning ettevõtlusõppe diferentseerimise vajadust, mis lähtub õppijate varasemast elu- ja töökogemusest, nende ettevõtlusõppele eelnenud erialasest õppest, enesearendamise sihtidest ning vajadusest leida ettevõtlusega alustamiseks ressursse.

Euroopa Komisjoni (2013) ettevõtluse tegevusplaanis aastaks 2020 märgitakse kogu Euroopa Liidu probleemina noorte kui ettevõtlusõppe olulise sihtrühma vähest entusiasmi ettevõtja karjääritee valikul ning käsitletakse ettevõtlust majanduskasvu ja tööhõive vahendina. Ettevõtlikkust nähakse professionaalsete karjäärivõimaluste olulise eeldusena ning ettevõtlusõpet seega noorte tööhõive toetajana (European Commission, 2013). Elanikkonna vananemise tõttu väärivad Eesti oludes peale noorte ettevõtlusõppe sihtrühmadena tähelepanu ka pikaajalise töökogemusega inimesed, kes majanduse struktuurimuutuste tagajärjel on kaotanud või võivad lähiajal kaotada senise töökoha.

Uurides Soome õpetajate hinnanguid nende ettevõtluskoolitusele, tõdevad Rönkkö ja Lepistö (2015), et tõhus ettevõtlusõpe ei eelda standardiseeritud õppekava, vaid ainulaadseid dialoogilisi suhteid üliõpilaste, koolitajate, institutsioonide ja kogukondade vahel, kes mõjutavad konkreetset haridusprotsessi. Soome õpetajad ei näe hariduse mõtet ettevõtjate arvu kasvatamises, vaid rõhutavad kriitilise mõtlemise tähtsust ettevõtluse edendamisel. Selleks tehakse Soome üldhariduskoolides eri õppeainete vahel koostööd, käsitledes kaasava ühiskonna ja ettevõtluse temaatikat seostatuna (ibid.).

Ettevõtlusõppe olulisi sihtrühmi aitab piiritleda ettevõtlusõppe eesmärkide mõtestamine ettevõtluse eri määratlustest ja ettevõtlustüüpidest lähtudes. Audretsch, Kuratko ja Link (2015) tõdevad, et kõiki ettevõtluse kui mitmetahulise mõiste käsitlusi ei ole otstarbekas taandada ühele definitsioonile. Nad peavad vajalikuks lähtuda ettevõtluse sisu avamisel nii organisatsiooni, indiviidi või tiimi staatusest ettevõtjana kui ka käitumuslikest määratlustest, mis rõhutavad tegevusi ärivõimaluste avastamiseks või loomiseks, indiviidi ettevõtlikku mõtteviisi või organisatsiooni kui terviku personali ettevõtlikku käitumist.

18. sajandil ühena esimestest ettevõtja majanduslikku rolli tähtsustanud Richard Cantilloni (1959) jaoks määras ettevõtluse olemuse asjaolu, et ettevõtja kannab kaupu ostes riski, sest kaupade müügihind ei ole ostu hetkel 
teada. 21. sajandil on kiirelt muutuva majanduskeskkonna ja tehnoloogiliste võimaluste tõttu ajateguriga seotud riskid ettevõtluses veelgi olulisemad. Ka Eestis aastatel 2012-2014 ellu viidud globaalse ettevõtlusmonitooringu küsitlused on näidanud, et kartus ettevõtluses ebaõnnestuda on Eesti elanikkonna hulgas üks põhitegureid, mis takistab ettevõtlusega alustamist (Eesti Arengufond, 2015). Seetõttu tulebki ettevõtlusõppes selgitada ettevõtlustüüpide riskiastmete erinevusi ja arendada pädevusi, mis aitavad riske hinnata, ettevõtja riskitaluvusele vastavaid ärivõimalusi leida ja riske sobivate vahendite abil maandada. Ettevõtlusõppe sihtrühmana vajavad õppijad, keda takistab ettevõtlusega alustamast kartus ebaõnnestuda, sellist ettevõtlusõpet, mis tugevdab ettevõtlusmotivatsiooni ja eneseusku. Lahenduseks võib olla edukate ettevõtjate kogemuse analüüsimine ja ettevõtluspraktikute rakendamine mentoritena. Mida uuenduslikum on ettevõtlusalgatus, seda olulisem on kõrvuti loovusega ka riskide käsitlemise pädevus.

Gartner (1989) soovitab määratleda ettevõtlust uue organisatsiooni loomise protsessi kaudu. Protsessipõhistest ettevõtluse määratlustest lähtumine avab uued perspektiivid ettevõtlusõppe eesmärgistamiseks olukorras, kus uue organisatsiooni loomine on äriidee elluviimise paratamatu eeldus ning kus on seatud eesmärgiks integreerida ettevõtlusõpe, eelinkubatsioon ja inkubatsioon ning toote või teenuse turuleviimine. Samas võib ettevõtlus toimida ka leiundustegevuse kaudu, mille tulemus müüakse maha intellektuaalomandina, loomata selleks uut äriühingut. Ettevõtlikkust toetavas suures organisatsioonis võib ettevõtlus rakenduda organisatsioonisisese ettevõtlusena, mille korral puudub vajadus uue äriühingu järele (Kuratko, Hornsby, \& Hayton, 2015).

\section{Ettevõtlusorientatsioonid ja arendusprioriteedid}

Ettevõtete ümberkujundamise ja organisatsioonisisese ettevõtlusega on otseselt seotud organisatsiooni kui terviku ettevõtlusorientatsiooni uurimused. Nendes lähtutakse ettevõtlike organisatsioonide määratlemisel organisatsioonis omaksvõetud prioriteetidest. Ettevõtted, kus tegutsetakse innovaatiliselt ja kus ei jääda äraootavale positsioonile, vaid pingutatakse selle nimel, et siseneda turule esimesena, ning võetakse riske, suudavad suurema tõenäosusega uusi ärivõimalusi avastada ja ära kasutada. Näiteks on Lumpkin ja Dess (1996) arendanud välja ettevõtlusorientatsiooni käsitluse, mis seostab organisatsiooni ettevõtliku tegutsemise innovaatilisuse, proaktiivsuse, riskivõtmise, autonoomia ja võistlusliku agressiivsusega. Ettevõtte asutajad püüavad organisatsiooni arengut suunata selle järgi, millised on nende enda ettevõtlusorientatsiooni tugevad küljed (Lumpkin \& Lichtenstein, 2005). 
Lumpkini ja Dessi (1996) nimetatud viis ettevõtlusorientatsiooni elementi võivad ka omavahel vastuollu sattuda, nt avatud innovatsiooni põhimõtete rakendamisel. Kui ettevõte paistab silma agressiivsusega konkurentsivõistluses ega otsi vastastikku kasulikke koostöövõimalusi, on tal raske eeldada, et tema partnerid on valmis innovaatilisi tooteid ühiselt arendama ja kasutama. Eeltoodud vastuolusid arvestades on Elenurm ja Moisala (2008) töötanud välja metoodika, mis võimaldab eristada parimaid tavasid jäljendavat, individuaalselt uuenduslikku ja koosloovat ettevõtlusorientatsiooni ning selgitada ettevõtlusõppes osalejate enesehindamise kaudu välja iga osaleja eelistused nende kolme ettevõtlusorientatsiooni suhtes. Selline ettevõtlusorientatsiooni analüüs aitab ettevõtlusõppes osalejatel mõtestada, millised oleksid nende valikud, kui nad tegutseksid individuaalse ettevõtjana, ettevõtlustiimis või organisatsioonisisese ettevõtjana.

Ettevõtlik organisatsioon kasvab, rakendab uuenduslikke ideid, toob tulu omanikele ja/või loob uut väärtust ühiskonnale. Schumpeter (1934) seostab ettevõtluse olemuse loova hävitamisega, turu tasakaalu lõhkuva ja olemasolevaid äritegevuse valdkondi tarbetuks muutva radikaalse innovatsiooniga, mis viib ettevõtluse kvalitatiivselt uuele arengutasemele. Seejuures käsitleb ta ettevõtjatena kõiki, kes mõjutavad innovatsiooniprotsessi oluliselt, ka investoreid, kes ettevõtte igapäevast tegevust ei juhi. Schumpeteri innovatsioonikesksele ettevõtluse käsitlusele vastandatakse tihti Kirzneri (1973) arusaam, et tänu informeeritusele turuhäiretest suudab ettevõtja tulu teenida just turul tasakaalu luues. Ettevõtja funktsioon on osta sisendressursse sealt, kus hind on majandussüsteemi kui terviku seisukohalt põhjendamatult odav, ja rakendada saadud ressursse äriprotsessis, kus eeldatava tulemi hind on kõrgem. Ettevõtja tasakaalustab pakkumist ja nõudlust. Kirzneri tõlgenduses on ettevõtja oportunist, kes suudab sageli edu saavutada ka põhjendamatute õigusnormide ja piirangutega kammitsetud majanduses, kus poliitikud nimetavad teda halvustavalt spekulandiks. Schumpeteri käsitlusest lähtudes saame tuletada ettevõtlusõppe eesmärgi ja sisu sünnilt globaalsete ettevõtete tarbeks, kus uudse tehnoloogia või ärimudeli abil püütakse saavutada tulemust, mis eeldab uue turu ja innovatsiooni ökosüsteemi loomist (Adner, 2012). Kirzneri turuhäiretele reageerimise loogikat ei saa kõrvale jätta, kui selgitatakse, milliseid ettevõtlusvõimalusi pakub väärtpaberiturg või kinnisvaraturu mullide teke ja lõhkemine. Mõlema käsitluse esitamine annab raamistiku tähtsale valikule - kas äriedu tahetakse saavutada maailma muutva innovatsiooniga või turu anomaaliaid ära tundes, õigel ajal ja õiges kohas ärivõimalusi kiiresti ära kasutades?

Varasemad uuringud on näidanud, et tavapärase ettevõtluse alusõppe mõju ettevõtlusaktiivsusele ei ole alati ühetähenduslikult positiivne. Tuginedes 32 riigi võrdlusuuringule, osutavad Walter ja Block (2016), et ettevõtlusõpe 
suurendab noorte valmisolekut luua ettevõte pigem sellistes riikides, kus institutsionaalne keskkond on ettevõtluse suhtes vaenulik ja ei ole avaldanud ettevõtlusaktiivsuse suurendamiseks otsest positiivset mõju seal, kus ärikeskkond on ettevõtluse jaoks soodne. Samuti on 2827-t Norra kõrgkoolilõpetajat hõlmanud uuringust ilmnenud, et ettevõtluserialadel kõrgkooliõpingute lõpetajate hulgas ei ole lõpetamisele järgneva viie aasta jooksul enda ettevõtte loomise kavandajaid rohkem kui teistel erialadel. Kõige sagedamini kavandavad enda ettevõtte loomist spordivaldkonnas magistrikraadi saajad (Støren, 2014). Fayolle ja Gailly (2015) osutavad empiirilisele uuringule toetudes, et ettevõtlusõpe võib tugevdada nende üliõpilaste positiivseid hoiakuid ettevõtluse suhtes, kes varem ei olnud mõelnud ettevõtja karjäärist, nõrgendades samas ettevõtlusega juba kokku puutunud või perekondlikel põhjustel selles vallas eelteadmisi omavate noorte positiivseid hoiakuid ja ettevõtluskavatsusi. Selle põhjus võib seisneda asjaolus, et ettevõtlusõppe tulemusena mõistetakse varem alahinnatud raskusi paremini.

Uurides Eestis ettevõtluskursusel osalenud insenerierialade üliõpilaste arusaamu ettevõtlusõppe tähendusest õppijate edasise tegevuse jaoks, leiavad Täks, Tynjälä ja Kukemelk (2016), et ühtede jaoks oli see kursus allikas ideede rakendamiseks insenerina, teiste jaoks võimalus luua uus ja sügavam arusaam ettevõtluse teemavaldkonnast, kolmandate jaoks tegevusele orienteeritud isikliku arengu impulss ja neljandate jaoks eneseteostus meeskonnatöös. Autorid rõhutavad ettevõtlusõppes omandatud oskuste seotust õppedistsipliinide piire ületava meeskonnatööga, teadlikkusega sotsiaalsetest ja eetilistest kaalutlustest ning elukestva õppega. Seega võib ettevõtlusõpe anda vahetu impulsi ettevõtlusprotsessi käivitamiseks, kuid tulemus võib olla ka ettevõtlik käitumine laiemas mõttes. Et selgitada ettevõtlusõppe pikemaajalisi tulemusi Eesti kontekstis, oleks otstarbekas küsitleda üliõpilasi, kes osalesid 3-5 aastat tagasi ettevõtte loomisele keskendunud ettevõtlusõppes. See võimaldaks uurida, kuhu nad on tegelikus ettevõtluses praeguseks jõudnud. Ühtlasi annaks küsimustik väärtuslikku tagasisidet selle kohta, kuidas suurendada seda tüüpi ettevõtlusõppe tulemuslikkust ja senisest enam kaasata edukalt ettevõtet arendanud vilistlasi ettevõtlusõppesse.

O'Connor (2013) eristab nelja ettevõtlushariduse lähtepunkti, mis mõjutavad ettevõtlusõppe sihtrühmade vajaduste arvestamist. Esimene neist on arusaama kujundamine edukatele ettevõtjatele omastest rollidest ja omadustest. Eneseanalüüsiküsimustike abil saavad õppijad hinnata enda sobivust eri tüüpi ettevõtluseks ning kujundada seejärel enesearendamise visioon ettevõtluses osalemiseks. Õppe käigus kohtutakse edukate ettevõtjatega, analüüsitakse nende kogemusi ja saadakse innustust eeskujudest. Selline õppeviis tuleb ettevõtluse alusmoodulis kasuks eriti neile, kes ei ole enda huvi ettevõtluse vastu 
ja võimalikku arengurada ettevõtjana veel määranud. Selle ettevõtlusõppe faasi eesmärk on saavutada pädevus, mis võimaldab seada ettevõtlusega seotud enesearengusihte. Ettevõtlusõpet, mis aitab õppijatel mõista ja kriitiliselt analüüsida laiemaid ettevõtlustrende ühiskonna kui terviku arengu taustal, positsioneerida ennast iseseisva ja organisatsioonisisese ettevõtluse, samuti ettevõtluse majanduslike ja sotsiaalsete sihtide suhtes ning kavandada enda karjäriteed ja enesearendamist pikas perspektiivis, ei tohiks kindlasti alahinnata.

Ettevõtlusprotsessile keskenduv ettevõtlusõpe lähtub ärivõimaluste otsimisest, loomisest, analüüsimisest ja hindamisest. Õppeprotsessis selgitatakse äriplaani koostamiseks ning ettevõtte asutamiseks ja arendamiseks vajalikke edasisi tegevusi, kasutades kaasusi ja harjutusi. Õppijatelt siiski ei oodata õpingute jooksul ettevõtte loomist, sest kõigi ettevõtlustüüpide puhul ei ole nii ressursipiirangute kui ka õppijate ebapiisava valmisoleku tõttu seda reaalne teha.

Praktilise ettevõtluse kui óppemeetodi terviklikul rakendamisel läbitakse tegelik ettevõtte loomise protsess ja refleksioonifaas, õpitakse tegevuse kaudu. Praktilise ettevõtluse rakendamine õppemeetodina ehk õppimine ettevõtluse kaudu on lihtsam neil erialadel ja ettevõtlusvaldkondades, kus ei ole vaja suuri investeeringuid ning kus toote või teenuse prototüübi loomine ja katsetamine turul on lühikese ajaga võimalik.

Õppimine ettevõtluse jaoks tähendab valmistumist ettevõtjale oluliste õigete valikute tegemiseks ja ettevõtte loomiseks. Sedalaadi õppimine ei anna nii konkreetset ja kiiret tulemust kui õppimine praktilise ettevõtluse kaudu, kuid on paratamatu juhul, kui ettevõtlusõppe sihtrühm ei ole valmis kohe ettevõtlusega alustama, ei oma selleks piisavalt ressursse või kui valitud ettevõtlusvaldkonnas vigade tegemisega kaasneb suur risk.

\section{Ettevõtlustüüpide mõju ettevõtjate arendamise võimalustele}

Schindehutte, Morris ja Kuratko (2000) rõhutavad ettevõtlustüüpide klassifitseerimise tähtsust ettevõtluse uurimisel ja ettevõtjate arendamisel. Paljude autorite klassifikatsioone üldistades toovad nad esile mitu ettevõtlusloogika seisukohalt olulist klassifikatsioonialust: tegevusvaldkond ja kasvuambitsioon, ärimudel ja ettevõtlusesse sisenemise viis (sh uue toote loomine, tegutseva ettevõtte omandamine või frantsiis), ettevõtte elutsükli faas, ettevõtluse finantseerimise allikad, ettevõtja erialane taust ja põhipädevus. Nad peavad vajalikuks eristada ettevõtjaid-käsitöölisi, tehnoloogilisest arendusest lähtuvaid ettevõtjaid, individuaalseid ja tiimile toetuvaid uuendajaid, tugeva müügitegevuse või äriideede genereerimise võimekusega ettevõtjaid ning stabiilsete väikeettevõtete omanikke (ibid.). 
Ettevõtluskäsitlustes on varasematel aastakümnetel palju tähelepanu pööratud ettevõtja kui indiviidi tunnusjoontele (Shane \& Venkataraman, 2000), kuid üha tähtsamaks muutuvad ettevõtluse kollektiivsed ilmingud nii asutajate tiimides kui ka ühistutes, strateegilistes liitudes, ettevõtlusvõrgustikes, eri organisatsioonide töötajate koostöövõrgustikes ja organisatsioonis endas (Forsström-Tuominen, Jussila, \& Kolhinen, 2015). Uutest, alles kujunevatest ettevõtlusõppe sihtrühmadest väärivad eritähelepanu osakoormusega mikroettevõtluses osalejad, kelle tegevust võimaldab jagamismajandus, nagu Uberi taksojuhtidel (Richter, Kraus, \& Syrjä, 2015).

Ettevõtlusega alustamise motiive ja ambitsioone arvestades tuleb ettevõtlusõppes erinevalt läheneda nii vajaduspõhisele ettevõtjale, kelle tõukejõuks võib olla palgatöö võimaluse puudumine, harrastustest lähtuvale elustiiliettevõtjale, sissetöötatud ärimudelit rakendavale ettevõtjale, kes taotleb stabiilset kasvu, kui ka uut ärivõimalust loovale innovaatilisele ettevõtjale, kes on seadnud sihiks kasvu. Ettevõtlusega alustamise motiividest võib esikohal olla soov teenida kiiret kasumit, rajada jätkusuutlik äri või edendada sotsiaalset ettevõtlust. Ettevõtlusega võib innustada alustama kogukonna kultuuripärand (Summatavet \& Raudsaar, 2015). Sellist mitmekesisust silmas pidades on paratamatu, et osa õppijatest keskendub ärimudeli innovaatilisele arendusele, teised aga on oma hoiakutelt „ostan odavalt ja müün kallilt“ ärivõimaluste oportunistlikud kasutajad. Mõlemal juhul pakub ettevõtlusõppes osaleja jaoks plusse ja miinuseid nii üksikettevõtjana tegutsemine, mis võimaldab kiireid ja paindlikke otsuseid, kui ka sellise arenguraja järgimine, mis kasutab ettevõtlustiimi sünergiat ja partnerite ressursse.

Eesti ärikeskkonnas juhindutakse eri tüüpi kasvuloogikast: ettevõtete kasvu finantseerimiseks toetutakse kasumi reinvesteerimisele, pangalaenudele või äriinglitele ja riskikapitalile, samuti arendatakse kodu- või välisturgu sihtiva ettevõtluse jaoks olulisi pädevusi. Ettevõtlusõppe eesmärke püstitades tuleb arvesse võtta, kui spetsiifilisi valdkonnapõhiseid erialaseid pädevusi eeldatakse ühes või teises ettevõtlusvaldkonnas tegevusega alustamisel, sest algfaasis on ettevõtjal enamasti raske palgata valdkonda hästi tundvaid spetsialiste, kes tema erialaste teadmiste puudujääki tasakaalustaks. Ettevõtja tegevusvaldkonnast sõltub, millisel määral saab ja tuleb ettevõtlusõpet integreerida sihtrühma erialaõppesse. Näiteks seostub võimalus saada ettevõtja-käsitöölisena või remonditööde teenuste pakkujana iseendale tööandjaks paljude kutsehariduse valdkondadega, kus sobivaks ettevõtlusvormiks võib olla füüsilisest isikust ettevõtjana tegutsemine, mille korral ei ole vaja teha finantsriskidega seotud suuri investeeringuid. Samas on investeerimismahukates ettevõtlusvaldkondades eriti oluline ettevõtlusõppe tihe seos finantsainetega. 
21. sajandi esimestel aastakümnetel on ettevõtluse uurijad ja arendajad diskuteerinud elavalt selle üle, kas ettevõtjate siht peaks olema objektiivselt eksisteerivate ärivõimaluste otsimine ja äratundmine (DeTienne \& Chandler, 2004) või uute võimaluste loomine (Alvarez \& Barney, 2007; McGrath \& MacMillan, 2000). Seda diskussiooni võib selgitada konstruktivismi kriitilisest analüüsist lähtudes (Ramoglou \& Zyglidopoulos, 2015), kuid ettevõtluspraktika kontekstis saab uute ärivõimaluste loomist seostada ka ettevõtja aktiivse tegevusega uute turgude ja tarbimisviiside kujundamisel. Et uute ärivõimaluste loojate sihtrühm saavutaks ettevõtlusõppe eesmärgid, on otstarbekas pakkuda neile loovustreeninguid, mis süvendavad loovat mõtlemist. Õppetöös saab näidetena kasutada õppijate endi määratud uute ärivõimaluste otsingu suundi. Lisaks on selle sihtrühma jaoks oluline võimalus luua enda uudse idee rakendamiseks vajalik laiem innovatsiooni ökosüsteem (Adner, 2012). Seetõttu on ettevõtlusõppe üks eesmärke panna alus koostöövõrgustike kujundamise pädevusele ning võimaluse korral luua need võrgustikud ka tegelikult ja toetada nende laiendamist.

Eestis on viimastel aastatel palju tähelepanu pööratud ettevõtjatele, kes valideerivad oma ärimudelit säästliku idufirma (lean start-up’i) põhimõttel. Selle sihtrühma ettevõtlusõpe võib peale ärimudeli loomise sisaldada ka selle valideerimist klientidega tegevusõppe kaudu. Kõigis tegevusvaldkondades ei ole aga selline lähenemisviis tehnoloogiliselt nii lihtne kui veebirakenduste väljatöötamisel. Ettevõtlusõppes, kus keskendutakse uue organisatsiooni loomise protsessile näiteks tudengiettevõtete vormis, on oluline jõuda selgusele, kas sellises õppeprotsessis osalejad soovivad ka tegelikult loodavat ettevõtet edasi arendada ja ennast õpingute käigus alustatud ettevõtlusega pikaks ajaks siduda. Kui vastus on „jah“, siis on ettevõtlusõpet otstarbekas seostada eelinkubatsiooniga ning tutvustada õppijatele inkubatsiooni ja ettevõtluskiirendite võimalusi.

Kwong ja Thompson (2016) osutavad, et kuigi ülikoolide ettevõtlusõppes on viimasel aastakümnel pööratud palju tähelepanu tegevusõppele sihiga panna ettevõtte loomise protsessile alus juba õpingute käigus, peab enamik ettevõtlusõppes osalenuid mõistlikumaks peale õpingute lõpetamist saada esmalt kogemusi töövõtjana, et vähendada ettevõtjana ebaõnnestumise riski. „Lähen ja alustan ettevõtjana nüüd ja kohe“ suhtumisega noorte ja „Ootame, näeme" tüüpi potentsiaalsete ettevõtjate erinevus võib vähemalt osaliselt tuleneda ettevõtlikest hoiakutest. Ettevõtluskavatsuse tekke ja tegeliku uue ettevõtte loomise protsessi vahel võib olla põhjendatud ajanihe, mis tuleneb vajadusest õppida tundma tegevusharu spetsifikat ning luua ressursibaas, sh finantseerimisvõimalused ja koostöövõrgustik. Kwong ja Thompson (2016) järeldavad uuringutest, et ettevõtja kiire arenguraja valinud noored peavad ennast sagedamini loomulikeks liidriteks, kuid on käitumuslikult orienteeritud pigem 
sellisele ettevõtluspraktikale, mis tugineb lühikese ajahorisondiga kulusäästul, samas kui ettevõtte loomist edasi lükkavad üliõpilased on rohkem orienteeritud pikaajalist arendustööd eeldavatele tooteuuendustele. Ka 34 riigi andmetel põhinev GUESSi võrdlusuuring näitab, et vaid 6,6\% ettevõtlusõppes osalenud üliõpilastest soovib enda ettevõttes töötada kohe peale õpinguid, aga viie aasta pärast soovib seda teha 33,7\% üliõpilastest (Sieger, Fueglistaller, \& Zellweger, 2014). Üliõpilaste varasem töökogemus mõjutab äriidee ja kontaktide leidmist ning ressursside hankimist. Euroopa keskmisega võrreldes on aktiivselt ettevõtteid asutavad Eesti ja Ungari üliõpilased vanemad, Soome üliõpilased aga nooremad (Venesaar, Kallaste, \& Küttim, 2014a).

Seades eesmärke ettevõtlusõppele, mille keskmes on ettevõtte asutamine, tuleb arvestada ka täiskoormusega päevaõppe ja sessioonõppe eripära. Sessioonõppes osalejate hulgas on rohkem vanemaid üliõpilasi, kes juba on ettevõtjad, kuid ka tasuvat palgatööd tegevaid inimesi, kellele võib palgatöö asendamine ebakindla ja ettevõtte loomise algfaasis enamasti puuduva ettevõtlustuluga tähendada suurt riski perekonna sissetulekutele. Päevaõppes täiskoormusega osalevatel noortel on lihtsam ennast uue ettevõtte arendusprojektis proovile panna, kuid loodavate ettevõtete jätkusuutlikkust võib vähendada elu- ja töökogemuse ning ressursside ebapiisavus.

Et mõista ettevõtliku tegevuse arendamise võimalusi ja piiranguid, on ettevõtlusõppes vaja arvesse võtta organisatsioonide suurust ning sotsiaalseid ja ärieesmärke, ettevõtja positsiooni ning rolli omanike hulgas ja ettevõtte juhtimises. Sotsiaalse ettevõtluse kitsam käsitus eeldab, et sellise ettevõtlusega ei taotleta kasumit, seevastu laiema käsituse kohaselt on võimalik täita sotsiaalseid eesmärke ka kasumit taotlevates korporatsioonides (Austin, Stevenson, \& Wei-Skillern, 2006; Porter \& Kramer, 2011). Hechavarría ja Welter (2015) on võrrelnud sotsiaalseid eesmärke püstitavaid ja mittepüstitavaid ettevõtjaid, kes alustavad äritegevust, ning jõudnud järeldusele, et esimesed neist on innovaatilisemad. Sotsiaalse suunitlusega ettevõtjate innovaatilisus avaldub ka uudsetes ärimudelites. Nii näiteks soovitavad Zahra ja Wright (2016) loovalt integreerida ärimudeleid, mis on rajatud korporatsiooni sotsiaalsele vastutusele, sotsiaalsele ettevõtlusele ja n-ö püramiidi põhjale, st ühiskonna vaesema osa vajaduste rahuldamisele ja vaesusest vabaneda püüdvate inimeste ettevõtlikkusele.

Volery ja Mazzarol (2015) rõhutavad, et ettevõtlus seostub nii väikeste kui ka suurte organisatsioonidega, kus omanike mõju ettevõtlusele võib olla otsene või vahendatud. Ettevõtlusõppes tuleb eraldi läheneda stabiilsuse saavutanud väikeettevõtjatele, kellel on turu laiendamise võimalused piiratud ja kellel tuleb kasumi säilitamiseks palgakulude kasvu korral otsida võimalusi säilitada kulutõhusus. Seda tüüpi ettevõtja ootab ettevõtlusõppe sihtrühmana enamasti konkreetseid soovitusi, mida saaks kohe rakendada, kuigi tema probleemid 
võivad tuleneda hoopis pikaajalise kasvustrateegia puudumisest. Selle sihtrühma jaoks on ettevõtlusõppes oluline saavutada pikaajalise strateegilise mõtlemise pädevus ja jagada praktilist teavet teiste ettevõtjatega.

Ettevõtlusõppest saadud kogemused loomemajanduse valdkonnas on näidanud, et ettevõtlusoskuste arendamine on tulemuslikum, kui see integreeritakse praktilise loometegevusega (Daniel \& Daniel, 2015). Kujutava kunsti, teatri ja muusika valdkonnas peavad ettevõtluse ning ettevõtlikkuse arendajad ettevõtlushariduse keskseks ülesandeks seostada väline, ärile suunatud tõukejõud õppijate sisemise loomingulise eneseteostusega (Pollard \& Wilson, 2014). Heikkinen ja Stevenson (2016) on ühe selleks sobiva õppekorraldusliku mudelina analüüsinud stuudioõpet, mis toetub konstruktivistlikule õpikäsitusele ning loob sobiva keskkonna kogenud professionaalide kaasamiseks ja eri õppedistsipliine seostavaks tiimitööks. Turismialast ettevõtlusõpet uurides on Nieminen ja Lemmetyinen (2015) jõudnud järeldusele, et selles valdkonnas on edukuse oluline eeldus õppijate võimekus osaleda ärivõrgustikes ja õppivates kogukondades ning et ülikoolide panus võiks seisneda selleks sobivate foorumite loomises.

Ettevõtlusharidus on pälvinud tähelepanu Soome tervishoiusektoris (Salminen, Lindberg, Gustafsson, Heinonen, \& Leino-Kilpi, 2014). Eestis meditsiinihariduse saanute ettevõtlikkus avaldub praegu paljudel juhtudel teistesse riikidesse tasuvamale tööle siirdumises. Võib-olla aitaks süstemaatilisem ettevõtlusõpe osal Eesti meditsiinierialade lõpetajatest end Eesti ettevõtluses erialaselt ja samas tasuvamalt rakendada, selmet siirduda välismaale palgatööle. See on eriti tähtis, kuna Euroopa Liidus pakutakse patsientidele rohkem võimalusi kasutada meditsiiniteenusi piiriüleselt.

Penaluna jt (2015) rõhutavad maailma majandusfoorumi globaalse konkurentsivõime raportile toetudes vajadust seostada disainmõtlemine ja ettevõtlusõpe. Nad leiavad, et ettevõtlusvaldkonna koolitajad peaksid ise olema ettevõtlikud ja loovad, ületades õppedistsipliinide kunstlikku jaotust ja otsides uusi teadmiste loomise võimalusi just eri valdkondade õppeainete lõimimise kaudu (ibid.). See võimaldaks suurendada ka nende Eesti ettevõtjate arvu, kes saavutavad välisturul enda arendatud toodete ja kaubamärkide abil edu.

\section{Ettevõtlusõpe Eesti ettevõtluse rahvusvahelistumise toetajana}

Üks ettevõtlusõppe eesmärke Eesti väikeses avatud majanduses on valmistada õppijaid ette piiriüleseks ettevõtluseks, mis eeldab pädevust teha koostööd eri kultuuridest ja ettevõtluskeskkondadest mõjutatud äripartneritega. Rahvusvahelise võrdlusuuringu E-World raames tehtud küsitlustest on ilmnenud, et Eestis peetakse ettevõtluses edu saavutamiseks kõige olulisemaks läbirääkimis- 
oskusi, vastupidavust stressile ja innovaatilisust, samas kui USAs tähtsustatakse positiivsust, pidevat õppimist ja probleemide lahendamise võimet (Elenurm, Alas, Rozell, Scroggins, \& Alsua, 2014).

Ettevõtete rahvusvahelistumise mõjul on arenenud ettevõtluskeskkonnaga riikides viimastel aastatel rohkem tähelepanu pööratud rahvusvahelisele ettevõtlusorientatsioonile, mille üks ilminguid on sünnilt rahvusvahelised (born global) ettevõtted (Covin \& Miller, 2014). Morris, Neumeyer ja Kuratko (2015) selgitavad, et alustavad ettevõtjad, kes on rahvusvahelistumise ambitsiooniga, peaksid juba äriarenduse algfaasis tundma välisturgudele jõudmise arenguradasid, sh võimalust teha koostööd äriinglitega ja osaleda rahvusvahelistes koostöövõrgustikes. Nad peaksid olema võimelised osalema reflektiivses õppes ja ära tundma kriitilisi sündmusi (Lindh \& Thorgen, 2016), mis peegeldavad piiriülese äritegevuse riske ja määramatust. Et toetada innovaatilisi ettevõtlusalgatusi, mis on keskendunud kiirele kasvule ja globaalsele turule, ei ole enamasti otstarbekas seada ettevõtlusõppe fookusse üksikettevõtjad, vaid kasvuettevõtte jaoks olulist oskusteavet valdavate erialade esindajad, kes osalevad ärimudeli loomise protsessis tiimina.

Et minna rahvusvaheliselt allhankelt üle ettevõtja innovaatilist ärimudelit piiriüleselt rakendavale ettevõtlusele, tuleb tunda välisturgude arengusuundi ja laiendada koostööpartnerite võrgustikku. Varblane ja Tamm (2012) rõhutavad, et efektiivne koostöö eri organisatsioonide ja institutsioonidega võimaldab vähendada innovatsiooniprotsessi keerukust. Innovaatilise tootearenduse eeldus on koostöö investoritega, sh äriinglitega Eestis ja teistes riikides. Seevastu Eesti ettevõtlusõppe arendusprogrammi (EETA) uurimisprojektist „Äriinglite ja ühisrahastuse võimalused alustavale ettevõtjale" ilmnes, et ettevõtjate ja äriinglite koostöö arendamisel on Eestil arenenud investeerimiskeskkonnaga riikide kogemustest palju õppida. Intervjueeritud äriinglid soovisid, et ettevõtlustiimid tunneksid paremini sihtturge ja kliente ning suudaksid neil sihtturgudel ärimudeleid valideerida (Elenurm et al., 2017). See eeldab võimekust luua sihtturgudel kontakte juba äriarenduse varases faasis.

Globaliseerumine toob kaasa ettevõtjate ja potentsiaalsete ettevõtjate rahvusvahelise liikumise. Euroopa Liidus toetab seda Erasmuse üliõpilasvahetusprogramm, mille võimalusi piiriüleste ettevõtlustiimide loomiseks, aga ka juba loodud kasvuettevõtete rahvusvahelistumise toetamiseks annaks senisest rohkem kasutada. Enam ei saa pidada endastmõistetavaks, et kõik ettevõtlusest huvitatud üliõpilased loovad ekspordile orienteeritud ettevõtteid just enda sünnimaal või riigis, kus nad alustasid ülikooliõpinguid. Nad võivad uusi äriideid ja -partnereid leida ka teistest riikidest. Kedia ja Englis (2011) märgivadki, et ärikoolide rahvusvahelistumise võimalused ei piirdu vaid välisriikide üliõpilaste statsionaarsete õpingutega ülikooli asukohas, vaid avatud 
e-õppe kaudu saab ettevõtlusõppesse kaasata paljude riikide ettevõtlushuvilisi üliõpilasi. See loob paremaid võimalusi ka ülikooli koduriigi üliõpilaste rahvusvaheliste ettevõtlusvõrgustike laiendamiseks ning uute äriideede ja turgude leidmiseks.

Globaalse ettevõtlusmonitooringu 2012.-2014. aasta küsitluse tulemused Eesti kohta näitavad, kuivõrd olulised on tiimipõhine koosloov ettevõtlus kasvule orienteeritud rahvusvahelistes ettevõtlusalgatustes ja varajase faasi ambitsioonikate ettevõtjate rahvusvaheline võrgustumine. Rahvusvahelise kasvuambitsiooniga innovaatilised ettevõtjad on sageli toetunud teadmiste jagamisele teistest riikidest saabunud inimestega, samas kui Eesti siseturule orienteeritud ettevõtjad usaldavad teabeallikatena rohkem enda elukaaslasi ja sõprade lähiringi (Venesaar et al., 2014b).

Piiriülene ettevõtlus eeldab laiemat suhete võrgustikku ja mitmekesisemaid teabeallikaid kui kohalikule turule keskendunud ettevõtlus. Rõhutamist väärib, et piiriülese ettevõtlusena ei ole õige näha vaid Eestis valmistatud toodete eksporti. Piiriülene ettevõtlus võib hõlmata ka ärivõimaluste otsingut ning äriideede ja -mudelite ühist arendust piiriülestes tiimides või allhanget teistest riikidest. Rahvusvaheliste äritoimingute tulemuseks võib olla litsentside ost ja müük, rahvusvaheliste ühisettevõtete loomine nii Eestis kui ka mujal.

Eesti e-residentsuse programm loob võimalusi kaasata Eesti ettevõtlusesse andekaid noori arengumaadest, kus äriühingute registreerimine on keerukas ja ettevõtlusega kaasneb suur administratiivne koormus. Ettevõtlusõpe saab toetada noorte ettevõtjate rahvusvahelistumist selle eri etappidel: alates enda esmaste arendusideede piiriülesest tutvustamisest, partnerite otsimisest väljastpoolt ja nendega teabe jagamisest, usalduse loomisest tiimitööks kuni äriideede valideerimiseni sihtturgudel ja toimiva ärimudeli arendamiseni, arendustööks finantseerimisallikate leidmiseni ning uutele sihtturgudele jõudmiseni.

Et kujundada piiriülese võrgustumise oskusi, on vaja mõista teiste riikide üliõpilaste eelteadmisi ja hoiakuid ning kasutada tiimitöö alustamiseks nende kohta sotsiaalvõrgustikes kättesaadavat teavet. Estonian Business Schoolis on neli aastat korraldatud kursust „Ärivõimalused virtuaalvõrgustikes“, mille käigus analüüsitakse sotsiaal- ja ärivõrgustike strateegilist rolli üliõpilase karjääritee kujundamisel ja ettevõtlusvõimaluste otsingul ning harjutatakse veebipõhist koostööd EBSi Tallinna ja Helsingi õppekavadel õppivate üliõpilaste vahel. Seevastu ekspordimoodulisse kuuluval kursusel „Äriprojektid koostöös Balti riikide ettevõtjatega" on rahvusvahelise koosseisuga tudengitiimid tegutsenud n-ö väravaavajatena välisturgudele pürgivate kasvuettevõte jaoks, selgitades välja ja võrreldes eri sihtturgudele sisenemise võimalusi. Alates 2006. aastast on panustatud 79 projekti. Lisaks on EBSi üliõpilased rahvusvahelise äri aines viimastel aastatel osalenud X-Culture'i programmis, kus rakendatakse 
globaalseid tudengitiime, kes samuti analüüsivad kasvuettevõtete rahvusvahelise turunduse võimalusi ja koostavad uurimistulemuste kohta raporteid. Programmis järgitakse täielikult virtuaalse tiimitöö põhimõtteid, sest eri ülikoolide üliõpilaste vahetu silmast silma suhtlus on geograafilise distantsi tõttu võimatu. X-Culture'i programmis osaleb igal semestril kokku üle 2500 üliõpilase 80 ülikoolist ja 40 riigist. Tiimid luuakse kultuurilise ja geograafilise mitmekesisuse põhimõtete alusel. Enne tiimidesse jaotamist tuleb üliõpilastel läbida test, milles nad tõendavad enda teadmisi veebipõhiste teadmiste jagamise ja rahvusvahelise tiimitöö vahendite kasutamise kohta.

\section{Sihtrühmadele kohandatud ettevõtlusõppe rakendamise prioriteedid ja võimalused}

Ettevõtlusõppe oluliste sihtrühmade koosseis muutub ajas, sõltudes nii Eesti majanduse teadmusmahukuse kasvust ja rahvusvahelise konkurentsivõime muutustest kui ka majandustsüklitest. Eelkirjeldatud ettevõtlustüüpide käsitlusi üldistades ja õppijate tausta arvestades saab lähtuda üheksast ettevõtlusõppe sihtrühmade klassifitseerimise alusest:

1) ettevõtlusõppe haridustasand ja varasemates erialaõpingutes saavutatud pädevused kui ettevõtlusõppe alus;

2) töö- ja ettevõtluskogemus;

3) organisatsioonisisese või iseseisva ettevõtluse eelistamine;

4) ettevõtja eesmärkide seos sotsiaalsete ja regionaalsete arengusihtidega;

5) soov olla koosloova ettevõtlustiimi liige, üksikettevõtja või iseendale tööandja;

6) valmidus luua ettevõtlusõppe käigus tegelik ettevõte ja/või seda edasi arendada;

7) soov arendada skaleeritavat ärimudelit või tagada äritegevuse järkjärguline orgaaniline kasv;

8) ambitsioon välisturgudele siseneda ja rahvusvahelist ettevõtlust arendada;

9) residentsus: Eesti resident või mitteresident, kel on eeldused siduda end ettevõtlusõppe ja praktilise ettevõtluse kaudu Eestiga.

Ettevõtlusõppe arendamisel tuleks võimaluse korral õpet diferentseerida sihtrühmade õpivajaduste järgi. Samas õppevoorus osalejatel saab rakendada individualiseeritud õppe meetodeid, samuti on võimalik arendada sihtrühma vajadustele vastavaid valikaineid, õppemooduleid ja óppekavu. Artikli lisas ongi toodud näiteid sihtrühmade eripärast tulenevate ettevõtlusõppe diferentseerimise võimaluste kohta. Loetletud meetodite ja õppekorralduslike muudatustega nimekiri aga ei piirdu, vaid see on mõeldud täiendamiseks: just 
sedalaadi uute võimaluste leidmine ja loomine võiks olla õppeasutuste koostöö oluline siht Eesti ettevõtlusõppe arendamisel. Arvestada tuleks sedagi, et mõne sihtrühma erialaste oskuste läbimõeldud seostamine ettevõtlusõppes võib viia ettevõtluse arendamiseks vajaliku sünergiani. Head näidet selle kohta pakub disaini ja ärijuhtimise eriala üliõpilaste ühiskursus ning kogenud ettevõtjate tegevuspõhine ühisõpe ettevõtlusest huvitatud üliõpilastega, kes aitavad neil uute välisturgude kohta informatsiooni koguda.

Eesti Majandusteaduste Seltsi aastakonverentsil 28. jaanuaril 2016 korraldati rühmasessioon ja -arutelu selle kohta, mis sihtrühmad peaksid ettevõtlusõppe arendamisel olema Eesti majandusarengu kiirendamiseks lähiaastatel prioriteetsed. Rühmatöös osalenud 30 õppejõudu ja teadurit eri ülikoolide majandusteaduskondadest said arutelu lähtekohaks lisas esitatud tabeli, mida nad täpsustasid ja täiendasid. Rühmatöö tulemusena peeti vajalikuks arvestada ettevõtlusõppe arendamisel senisest paremini eelkõige järgmiste sihtrühmade õpivajadusi:

- sotsiaalne ettevõtja ning sotsiaalseid ja majanduslikke sihte ühendav hübriidettevõtja;

- ettevõtlusega alustaja, kes on üleilmse äriambitsiooniga ja tunneb huvi rahvusvahelistumise vastu;

- kogukondlik (ühistuline) ettevõtja, kes keskendub kohalike ressursside kasutamisele;

- pereettevõtlusega alustaja ja pereettevõtte üleandja (perekondliku järjepidevuse aspekt);

- teadus- ja arendustöö tulemuste rakendamisele orienteeritud ettevõtja, akadeemiline ettevõtja;

- organisatsioonisisene ettevõtja;

- ettevõtja digitaalses jagamismajanduses;

- töövõtjast ettevõtjaks karjääripööret tegevad noored, aga ka ettevõtlusega alustavad pensionieelikud ja pensionärid;

- majanduslike struktuurimuudatuste tõttu töötuks jäänud spetsialistid kui potentsiaalsed ettevõtjad.

Osa sihtrühmade õpivajaduste rahuldamine eeldab elukestva ja tasemeõppe seostamist. Ettevõtlusõppe arendamisel tuleb otsida eri ettevõtlustüüpide ja kontekstide ning õppekavade ühisosa. Tulemuste saavutamiseks on aga vaja arvesse võtta ka varasemate töö- ja ettevõtluskogemuste mõju ettevõtlusõppes osalejate eelteadmistele ning motivatsioonile alustada ettevõtlusega ja tegevuse kaudu õppida. 


\section{Kokkuvõte}

Kyrö (2015) sõnul on ettevõtluse uurijad ja arendajad ühisel arusaamal, et ettevõtluse tuum on ärivõimaluste käsitlemine, uute ettevõtete loomine, kasv, risk ning ressursside hankimine ja paigutamine. Ta rõhutab õppijate autonoomia ja valikute tähtsust ning vajadust arvestada ettevõtlusõppes Angloameerika ja Mandri-Euroopa kultuurierinevusi. Angloameerikalikus traditsioonis otsitakse vastust pragmaatilistele küsimustele „Mida?“ ja „Kuidas?“. Euroopas on kesksem küsimus „Miks?“, ettevõtluse koha mõtestamine laiemate väärtuste kontekstis. Ettevõtluse arengusuundade ja uute võimaluste mõtestamine nii Eesti ühiskonna väärtuste, tulevikustsenaariumide kui ka laiemate globaliseerumistrendide taustal annab õppijatele vajalikku lähteteavet enda rolli ja võimaliku arenguraja määramiseks ettevõtluses. Ka kriitiline hinnang „Ettevõtlus ei sobi mulle!“või „Võib-olla kunagi hiljem?“"võib olla ettevõtlusõppe väärtuslik tulemus, kui see põhineb sisulisel eneseanalüüsil ja põhjendatud valikutel.

Ettevõtlusõppe sihtrühmade vajaduste arvesse võtmine Eesti ettevõtlusõppe uuendamisel suurendab õppijate valikuvõimalusi, mille lähtepunkt on õppija enesemääratlus ja valmisolek tegevuse kaudu õppida. Kui valmisolekut praktilise ettevõtluse kui õppemeetodi rakendamiseks ei ole veel kujunenud, võib primitiivsele äriideele rajatud tudengiettevõtte imiteerimisest tulemuslikumaks osutuda selline õppeviis, mis võimaldab teha hilisema ettevõtluse jaoks õigeid valikuid ja hankida teavet alles kujunevate ettevõtlusvõimaluste kohta, pidades silmas nii kohalikku, regionaalset kui ka globaalset tasandit.

Ettevõtlusõppe arendamisel tuleb sõltuvalt ettevõtlustüübist arvestada ettevõtluse alustamiseks, tegevuse kaudu õppimiseks vajalikku ressursibaasi ja toote või teenuse väljaarendamise ajatsüklit ning seoseid ettevõtlus- ja erialapädevuste vahel, seda eriti tehnoloogiapõhise või loomeettevõtluse vallas. Siit tulenevad võimalused integreerida ettevõtlusõpet erialaainetega. Sihtrühmaspetsiifiliste õpivajaduste paremaks rahuldamiseks pakub palju võimalusi õppeasutuste koostöö uute valikainete ja ühismoodulite loomisel, mis toetab teadmiste jagamist eri erialade, kuid sama ettevõtlustüübiga seotud üliõpilaste vahel.

Eduka ettevõtluseni viivad mitmed arengurajad, mida ettevõtlusõpe saab arvesse võtta ja toetada. Nende hulka kuulub alustamine iseseisva või organisatsioonisisese ettevõtjana. Et arendada innovaatilist ja rahvusvahelise kasvuambitsiooniga ettevõtlust, tuleks ära kasutada edukalt rahvusvahelistunud ettevõtjate kaasustest saadud õppetunde. See, kuivõrd hästi suudetakse kujundada rahvusvaheliseks ettevõtluseks vajalikke pädevusi, sõltub aga ettevõtlusõppe integratsioonist rahvusvahelise äri ainevaldkonnaga ning piiriülesest võrgustumisest Eesti ja teiste riikide ettevõtlushuviliste noorte vahel. 
Välisriikide andekatele üliõpilastele ettevõtlusvõimaluste loomine Eestis ja vajaliku oskusteabe vahendamine saavad olla ettevõtlusõppe olulisteks sihtideks Eesti e-residentsuse programmi elluviimisel. Eesti ettevõtlusõpe võiks avatud e-õppe rakenduste kaudu olla kättesaadav neile teiste riikide noortele, kes tahavad Eestis ettevõtlusvõimalusi leida või ühistiimides Eesti üliõpilastega globaalsetel turgudel uusi ärivõimalusi luua.

\section{Tänusõnad}

Artikli kirjutamisel on toetutud programmi „Ettevõtlikkuse ja ettevõtlusõppe süsteemne arendamine kõigil haridustasemetel“ (EETA) kaudu saadud teabele ja kogemustele.

\section{Kasutatud kirjandus}

Adner, R. (2012). The wide lens: A new strategy for innovation. London: Penguin Group.

Alvarez, S. A., \& Barney, J. B. (2007). Discovery and creation: Alternative theories of entrepreneurial action. Strategic Entrepreneurship Journal, 1(1-2), 11-26. https://doi.org/10.1002/sej.4

Audretsch, D. B., Kuratko, D. F., \& Link, A. N. (2015). Making sense of the elusive paradigm of entrepreneurship. Small Business Economics, 45(4), 703-712. https://doi.org/10.1007/s11187-015-9663-Z

Austin, J., Stevenson, H., \& Wei-Skillern, J. (2006). Social and commercial entrepreneurship: Same, different, or both? Entrepreneurship Theory and Practice, 30(1), 1-22. https://doi.org/10.1111/j.1540-6520.2006.00107.x

Cantillon, R. (1959). Essay on the nature of trade in general. London: Frank Cass and Company.

Covin, J. G., \& Miller, D. (2014). International entrepreneurial orientation: Conceptual considerations, research themes, measurement issues, and future research directions. Entrepreneurship Theory and Practice, 38(1), 11-44. https://doi.org/10.1111/etap.12027

Daniel, R., \& Daniel, L. (2015). Success in the creative industries: The push for enterprising and entrepreneurial skills. Journal of Australian Studies, 39(3), 411-424. https://doi.org/10.1080/14443058.2015.1046896

DeTienne, D. R., \& Chandler, G. N. (2004). Opportunity identification and its role in the entrepreneurial classroom: A pedagogical approach and empirical test. Academy of Management Learning and Education, 3(3), 242-257. https://doi.org/10.5465/amle.2004.14242103

Eesti Arengufond (2015). Globaalne ettevõtlusmonitooring 2014. Eesti raport. Külastatud aadressil http://www.arengufond.ee/wp-content/uploads/2015/11/GEM_2014_Eesti1.pdf. 
Elenurm, T., Alas, R., Rozell, E. J., Scroggins, W. A., \& Alsua, C. J. (2014). Cultural prototypes of the successful entrepreneur: Comparison of Estonia and the United States. Journal of Baltic Studies, 45(4), 499-515. https://doi.org/10.1080/01629778.2014.938354

Elenurm, T., Lassur, S., Tafel-Viia, K., Joller, L., Hansen, K., \& Mühlberg, M. (2017). Äriinglite ja ühisrahastuse võimalused alustavale ettevõtjale. Külastatud aadressil http://ettevotlusope.edu.ee/wp-content/uploads/2016/09/Raport_ariinglite-jayhisrahastus_19.05.2017.pdf.

Elenurm, T., \& Moisala, A. (2008). Human resources for entrepreneurship: Comparing orientations of Estonian and Finnish business students. European Journal of International Management, 2(4), 454-470.

https://doi.org/10.1504/EJIM.2008.021248

European Commission (2013). Entrepreneurship 2020 action plan. Reigniting the entrepreneurial spirit in Europe, Brussels. COM (2012) 795 final. Retrieved from http://eur-lex.europa.eu/LexUriServ/LexUriServ.do?uri=COM:2012:0795:FIN: en:PDF.

Fayolle, A., \& Gailly, B. (2015). The impact of entrepreneurship education on entrepreneurial attitudes and intention: Hysteresis and persistence. Journal of Small Business Management, 53(1), 75-93. https://doi.org/10.1111/jsbm.12065

Forsström-Tuominen, H., Jussila, I., \& Kolhinen, J. (2015). Business school students' social construction of entrepreneurship: Claiming space for collective entrepreneurship discourse. Scandinavian Journal of Management, 31(1), 102-120. https://doi.org/10.1016/j.scaman.2014.08.001

Gartner, W. B. (1989). "Who is an entrepreneur?" is the wrong question. Entrepreneurship Theory and Practice, 13(4), 47-68. https://doi.org/10.1177/104225878901300406

Hechavarría, D. M., \& Welter, C. (2015). Opportunity types, social entrepreneurship and innovation: Evidence from the panel study of entrepreneurial dynamics. Entrepreneurship and Innovation, 16(4), 237-251. https://doi.org/10.5367/ijei.2015.0196

Heikkinen, K.-P., \& Stevenson, B. (2016). The LAB Studio model: Enhancing entrepreneurship skills in higher education. International Journal of Innovation and Learning, 20(2), 154-168. https://doi.org/10.1504/IJIL.2016.077846

Kedia, B. L., \& Englis, P. D. (2011). Transforming business education to produce global managers. Business Horizons, 54(4), 325-331. https://doi.org/10.1016/j.bushor.2011.02.006

Kirzner, I. M. (1973). Competition and entrepreneurship. Chicago: University of Chicago Press.

Kuratko, D. F., Hornsby, J. S., \& Hayton, J. (2015). Corporate entrepreneurship: The innovative challenge for a new global economic reality. Small Business Economics, 45(2), 245-253. https://doi.org/10.1007/s11187-015-9630-8

Kwong, C., \& Thompson, P. (2016). The when and why: Student entrepreneurial aspirations. Journal of Small Business Management, 54(1), 299-318. https://doi.org/10.1111/jsbm.12146

Kyrö, P. (2015). The conceptual contribution of education to research on entrepreneurship education. Entrepreneurship \& Regional Development, 27(9-10), 599618. https://doi.org/10.1080/08985626.2015.1085726 
Lindh, I., \& Thorgen, S. (2016). Critical event recognition: An extended view of reflective learning. Management Learning, 47(5), 525-542.

https://doi.org/10.1177/1350507615618600

Lumpkin, G. T., \& Dess, G. G. (1996). Clarifying the entrepreneurial orientation construct and linking it to performance. Academy of Management Review, 21(1), 135-172. https://doi.org/10.5465/amr.1996.9602161568

Lumpkin, G. T., \& Lichtenstein, B. B. (2005). The role of organizational learning in the opportunity-recognition process. Entrepreneurship Theory and Practice, 29(4), 451-472. https://doi.org/10.1111/j.1540-6520.2005.00093.x

Majandus- ja Kommunikatsiooniministeerium (2013). Eesti ettevõtluse kasvustrateegia 2014-2020. Külastatud aadressil http://kasvustrateegia.mkm.ee/.

McGrath, R. G., \& MacMillan, I. C. (2000). The entrepreneurial mindset: Strategies for continuously creating opportunity in the age of uncertainty. Boston: Harvard University Press.

Morris, M. H., Neumeyer, X., \& Kuratko, D. F. (2015). A portfolio perspective on entrepreneurship and economic development. Small Business Economics, 45(4), 713-728. https://doi.org/10.1007/s11187-015-9678-5

Nieminen, L., \& Lemmetyinen, A. (2015). A value-creating framework for enhancing entrepreneurial learning in networks. Journal of Enterprising Communities: People and Places in the Global Economy, 9(1), 76-91. https://doi.org/10.1108/JEC-04-2013-0012

O'Connor, A. (2013). A conceptual framework for entrepreneurship education policy: Meeting government and economic purposes. Journal of Business Venturing, 28(4), 546-563. https://doi.org/10.1016/j.jbusvent.2012.07.003

Penaluna, K., Penaluna, A., Usei, C., \& Griffiths, D. (2015). Enterprise education needs enterprising educators: A case study on teacher training provision. Education + Training, 57(8/9), 948-963. https://doi.org/10.1108/ET-03-2015-0016

Pollard, V., \& Wilson, E. (2014). The "Entrepreneurial mindset" in creative and performing arts higher education in Australia. Artivate: A Journal of Entrepreneurship in the Arts, 3(1), 3-22.

Porter, M. E., \& Kramer, M. R. (2011). Creating shared value. Harvard Business Review, 89(1/2), 62-77.

Ramoglou, S., \& Zyglidopoulos, S. C. (2015). The constructivist view of entrepreneurial opportunities: A critical analysis. Small Business Economics, 44(1), 71-78. https://doi.org/10.1007/s11187-014-9590-4

Richter, C., Kraus, S., \& Syrjä, P. (2015). The shareconomy as a precursor for digital entrepreneurship business models. International Journal of Entrepreneurship and Small Business, 25(1), 18-35. https://doi.org/10.1504/IJESB.2015.068773

Rönkkö, M. L., \& Lepistö, J. (2015). Finnish student teachers' critical conceptions of entrepreneurship education. Journal of Enterprising Communities: People and Places in the Global Economy, 9(1), 61-75. https://doi.org/10.1108/JEC-03-2013-0003

Salminen, L., Lindberg, E., Gustafsson, M. L., Heinonen, J., \& Leino-Kilpi, H. (2014). Entrepreneurship education in health care education. Education Research International. Retrieved from https://www.hindawi.com/journals/edri/2014/312810/. https://doi.org/10.1155/2014/312810 
Schindehutte, M., Morris, M. H., \& Kuratko, D. F. (2000). Classification as a factor in the scientific evolution of entrepreneurship. Journal of Small Business Strategy, 11(2), 1-20.

Schumpeter, J. A. (1934). The theory of economic development. Cambridge: Harvard University Press.

Shane, S., \& Venkataraman, S. (2000). The promise of entrepreneurship as a field of research. Academy of Management Review, 25(1), 217-226. https://doi.org/10.5465/amr.2000.2791611

Sieger, P., Fueglistaller, U., \& Zellweger, T. (2014). Student entrepreneurship across the globe: A look at intentions and activities. St.Gallen: Swiss Research Institute of Small Business and Entrepreneurship at the University of St.Gallen (KMUHSG). Retrieved from http://www.guesssurvey.org/resources/PDF_InterReports/ GUESSS_INT_2013_REPORT.pdf.

Støren, L. A. (2014). Entrepreneurship in higher education. Education + Training, 56(8-9), 795-813. https://doi.org/10.1108/ET-06-2014-0070

Summatavet, K., \& Raudsaar, M. (2015). Cultural heritage and entrepreneurship inspiration for novel venture creation. Journal of Enterprising Communities: People and Places in the Global Economy, 9(1), 31-44. https://doi.org/10.1108/JEC-03-2013-0010

Zahra, S. A., \& Wright, M. (2016). Understanding the social role of entrepreneurship. Journal of Management Studies, 53(4), 610-629. https://doi.org/10.1111/joms.12149

Zahra, S. A., Wright, M., \& Abdelgawad, S. G. (2014). Contextualization and the advancement of entrepreneurship research. International Small Business Journal, 32(5), 479-500. https://doi.org/10.1177/0266242613519807

Täks, M., Tynjälä, P., \& Kukemelk, H. (2016). Engineering students' conceptions of entrepreneurial learning as part of their education. European Journal of Engineering Education, 41(1), 53-69. https://doi.org/10.1080/03043797.2015.1012708

Varblane, U., \& Tamm, D. (2012). The development of the systemic approach to innovation. In E. G. Carayannis, U. Varblane, \& T. Roolaht (Eds.), Innovation systems in small catching-up economies (pp. 3-19). New York: Springer. https://doi.org/10.1007/978-1-4614-1548-0_1

Venesaar, U., Kallaste, M., \& Küttim, M. (2014a). Factors influencing students' venture creation process. Procedia - Social and Behavioral Sciences, 110, 678-688. https://doi.org/10.1016/j.sbspro.2013.12.912

Venesaar, U., Mets, T., Paes, K., Elenurm, T., Masso, J., Küttim, M., \& Konsa, P. (2014b). Globaalne ettevõtlusmonitooring 2013. Eesti raport. Tallinn: Estonian Development Fund.

Volery, T., \& Mazzarol, T. (2015). The evolution of the small business and entrepreneurship field: A bibliometric investigation of articles published in the International Small Business Journal. International Small Business Journal, 33(4), 374396. https://doi.org/10.1177/0266242613516139

Walter, S. G., \& Block, J. H. (2016). Outcomes of entrepreneurship education: An institutional perspective. Journal of Business Venturing, 31(2), 216-233. https://doi.org/10.1016/j.jbusvent.2015.10.003

Welter, F. (2011). Contextualizing entrepreneurship - conceptual challenges and ways forward. Entrepreneurship Theory and Practice, 35(1), 165-184. https://doi.org/10.1111/j.1540-6520.2010.00427.x 
Lisa. Ettevõtluskontekstide ja -tüüpide arvestamine ettevõtlusõppe kohandamisel sihtrühmadele

\begin{tabular}{|c|c|c|}
\hline $\begin{array}{c}\text { Ettevõtlusõppe } \\
\text { sihtrühm või kontekst }\end{array}$ & $\begin{array}{l}\text { Diferentseerimise } \\
\text { võimalik alus }\end{array}$ & $\begin{array}{c}\text { Ettevõtlusõppe uudsed } \\
\text { võimalused, sh sünergia } \\
\text { ettevõtlusõppe } \\
\text { sihtrühmade vahel }\end{array}$ \\
\hline $\begin{array}{l}\text { Noored, kellel puudub } \\
\text { enesemäärang iseseisva } \\
\text { ja organisatsioonisisese } \\
\text { ettevõtluse või } \\
\text { palgatöö eelistamiseks }\end{array}$ & $\begin{array}{l}\text { - Ettevõtluse tarbeks } \\
\text { enesearendamisvisiooni } \\
\text { kujundamine }\end{array}$ & - Ettevõtlusmentorlus \\
\hline Sotsiaalsed ettevõtjad & $\begin{array}{l}\text { - Sotsiaalsest väärtusest } \\
\text { lähtuv ressursside } \\
\text { koondamine }\end{array}$ & $\begin{array}{l}\text { - „Hooandja“ kaudu } \\
\text { rahastuse hankimise } \\
\text { praktikum }\end{array}$ \\
\hline $\begin{array}{l}\text { Vajaduspõhised } \\
\text { ettevõtjad, sh töötud }\end{array}$ & $\begin{array}{l}\text { - Ettevõtluseks sobivate } \\
\text { töötute eelduste } \\
\text { parandamine, et nad saaksid } \\
\text { end ettevõtjana rakendada }\end{array}$ & $\begin{array}{l}\text { - Töötuklubides } \\
\text { kontaktide loomine } \\
\text { töötute ja äriideedega } \\
\text { üliõpilaste vahel }\end{array}$ \\
\hline $\begin{array}{l}\text { Globaalse kasvu- } \\
\text { ambitsiooniga } \\
\text { ettevõtjad }\end{array}$ & $\begin{array}{l}\text { - } \text { Ettevõtte kiire } \\
\text { rahvusvahelistumise } \\
\text { võimalused, tegevused } \\
\text { välisturgudele sisenemiseks }\end{array}$ & 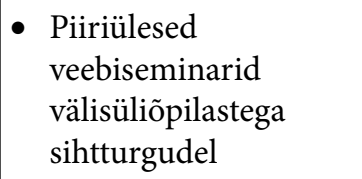 \\
\hline $\begin{array}{l}\text { Õpingute ajal ettevõtte } \\
\text { loomise poole } \\
\text { püüdlevad innovaati- } \\
\text { lised ettevõtjad }\end{array}$ & 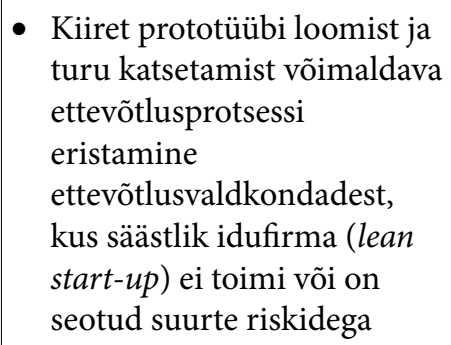 & 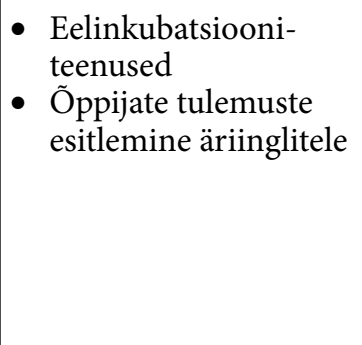 \\
\hline Pereettevõtjad & $\begin{array}{l}\text { - Pereettevõtte üleandmine } \\
\text { vanemalt põlvkonnalt } \\
\text { nooremale }\end{array}$ & $\begin{array}{l}\text { - Eri põlvkondade } \\
\text { esindajate ühisõpe }\end{array}$ \\
\hline $\begin{array}{l}\text { Digitaalses jagamis- } \\
\text { majanduses toimivad } \\
\text { mikroettevõtjad (nt } \\
\text { Uberi taksojuhid) }\end{array}$ & $\begin{array}{l}\text { - Jagamismajanduse äri- } \\
\text { mudelid ja isiklike } \\
\text { vahendite kasutamine } \\
\text { mikroettevõtluses }\end{array}$ & $\begin{array}{l}\text { - Teenuse osutaja või } \\
\text { kasutaja vaatlus }\end{array}$ \\
\hline
\end{tabular}




\begin{tabular}{|c|c|c|}
\hline $\begin{array}{c}\text { Ettevõtlusõppe } \\
\text { sihtrühm või kontekst }\end{array}$ & $\begin{array}{l}\text { Diferentseerimise } \\
\text { võimalik alus }\end{array}$ & $\begin{array}{c}\text { Ettevõtlusõppe uudsed } \\
\text { võimalused, sh sünergia } \\
\text { ettevõtlusõppe } \\
\text { sihtrühmade vahel }\end{array}$ \\
\hline $\begin{array}{l}\text { Mittetulundussektori } \\
\text { kogukonnapõhised } \\
\text { ettevõtjad }\end{array}$ & $\begin{array}{l}\text { - Kvaliteediga seotud } \\
\text { innovatsioon } \\
\text { - Teenuste mitmekesisus } \\
\text { ja vastavus kogukonna } \\
\text { vajadustele } \\
\text { - Kulueeliste realiseerimine }\end{array}$ & $\begin{array}{l}\text { - } \text { Teenusedisaini } \\
\text { meetodite rakenda- } \\
\text { mine } \\
\text { - } \text { MTÜde ettevõtlustulu } \\
\text { teenimise parimad } \\
\text { näited } \\
\text { - } \text { Kogukonna esin- } \\
\text { dajate kaasamine } \\
\text { projektitöösse }\end{array}$ \\
\hline $\begin{array}{l}\text { Koosloova orientat- } \\
\text { siooniga ettevõtjad }\end{array}$ & $\begin{array}{l}\text { - Ettevõtlustiimide loomine ja } \\
\text { tiimiotsused } \\
\text { - Ühistute võimalused, } \\
\text { plussid ja miinused } \\
\text { ettevõtluses } 21 \text {. sajandil }\end{array}$ & $\begin{array}{l}\text { - Tiimitöö treeningud } \\
\text { - Mõttetalgud }\end{array}$ \\
\hline $\begin{array}{l}\text { Virtuaalsetes ette- } \\
\text { võtlusvõrgustikes ja } \\
\text { avatud innovatsiooni } \\
\text { keskkondades } \\
\text { tegutsejad }\end{array}$ & $\begin{array}{l}\text { - } \text { Aktiivsed sotsiaalmeedia } \\
\text { kasutajad } \\
\text { - Sünergiapotentsiaaliga } \\
\text { ettevõtlusõppes osalejad eri } \\
\text { ülikoolidest ja riikidest }\end{array}$ & $\begin{array}{l}\text { - Virtuaalsete } \\
\text { praktikakogukondade } \\
\text { loomine } \\
\text { - Avatud innovatsiooni } \\
\text { keskkondade } \\
\text { kasutamine }\end{array}$ \\
\hline $\begin{array}{l}\text { Kunstnikud } \\
\text { ettevõtjatena }\end{array}$ & $\begin{array}{l}\text { - } \text { Kunstniku mainekujundus } \\
\text { - } \text { Meistri-õpipoiste koostöö } \\
\text { arendamine }\end{array}$ & - Stuudioõpe \\
\hline $\begin{array}{l}\text { Disainile toetuvad } \\
\text { ettevõtjad }\end{array}$ & $\begin{array}{l}\text { - Ettevõtjate ja disainerite } \\
\text { koostöö }\end{array}$ & $\begin{array}{l}\text { - Ettevõtluse ja disaini } \\
\text { eriala üliõpilaste } \\
\text { ühisõpe }\end{array}$ \\
\hline $\begin{array}{l}\text { Eri tüüpi loome- } \\
\text { ettevõtjad, sh elu- } \\
\text { stiiliettevõtjad ja } \\
\text { kasvuorientatsiooniga } \\
\text { loomeettevõtjad }\end{array}$ & $\begin{array}{ll}\text { - } & \text { Loomevaldkondade koostöö } \\
\text { - } & \text { Loomevaldkondade ja teiste } \\
& \text { ettevõtlusvaldkondade } \\
& \text { koostöö } \\
\text { - } & \text { Elustiiliettevõtluse } \\
& \text { jätkusuutlikkus }\end{array}$ & $\begin{array}{l}\text { - Loomevaldkondade } \\
\text { ja ettevõtluse eriala } \\
\text { üliõpilaste ühisõpe }\end{array}$ \\
\hline $\begin{array}{l}\text { Intellektuaalomandi } \\
\text { kommertsialiseerijad }\end{array}$ & $\begin{array}{l}\text { - Leiundustegevusele ja } \\
\text { loomeisiku tegevusele } \\
\text { orienteerunud üliõpilased } \\
\text { - Uurimis- ja arendustegevuse } \\
\text { valdkonna töötajad } \\
\text { ettevõtetes }\end{array}$ & $\begin{array}{l}\text { - Andmebaasidel } \\
\text { põhinevad } \\
\text { patendiotsingu- } \\
\text { harjutused }\end{array}$ \\
\hline
\end{tabular}




\begin{tabular}{|c|c|c|}
\hline $\begin{array}{c}\text { Ettevõtlusõppe } \\
\text { sihtrühm või kontekst }\end{array}$ & $\begin{array}{l}\text { Diferentseerimise } \\
\text { võimalik alus }\end{array}$ & $\begin{array}{c}\text { Ettevõtlusõppe uudsed } \\
\text { võimalused, sh sünergia } \\
\text { ettevõtlusõppe } \\
\text { sihtrühmade vahel }\end{array}$ \\
\hline $\begin{array}{l}\text { Ettevõtlikud juhid } \\
\text { suurettevõttes, } \\
\text { sisemise ettevõtluse } \\
\text { eeltingimuste loojad }\end{array}$ & $\begin{array}{l}\text { - Ettevõtlusorientatsiooni } \\
\text { arendamine suure } \\
\text { organisatsiooni juhtrühmas }\end{array}$ & $\begin{array}{l}\text { - } \text { Ettevõtlus- } \\
\text { orientatsiooni } \\
\text { hindamise metoodika } \\
\text { kasutamine }\end{array}$ \\
\hline $\begin{array}{l}\text { Organisatsioonisisese } \\
\text { ettevõtja karjääriks } \\
\text { valmistujad }\end{array}$ & 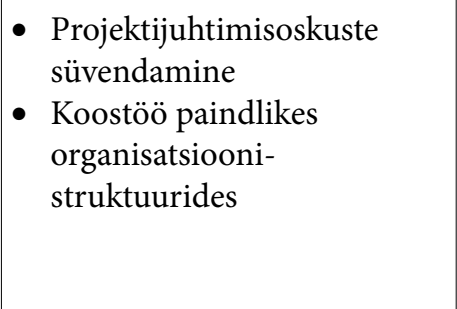 & $\begin{array}{l}\text { - Korporatiivse ülikooli } \\
\text { rakendused või } \\
\text { õppevormid, mis } \\
\text { põhinevad ülikoolide } \\
\text { ja rahvusvaheliste } \\
\text { suurfirmade } \\
\text { partnerlusel }\end{array}$ \\
\hline $\begin{array}{l}\text { Organisatsioonivälises } \\
\text { korporatiivses } \\
\text { ettevõtluses osalejad }\end{array}$ & $\begin{array}{l}\text { - Organisatsiooni } \\
\text { tütarettevõtte, ühisettevõtte } \\
\text { või iseseisvuva (spin-off) } \\
\text { ettevõtte loomise protsess }\end{array}$ & $\begin{array}{l}\text { - } \text { Tudengitiimide } \\
\text { rakendamine } \\
\text { korporatiivsete } \\
\text { riskiinvesteeringute } \\
\text { ettevalmistamiseks }\end{array}$ \\
\hline $\begin{array}{l}\text { Äriideede konkurssidel } \\
\text { osalejad }\end{array}$ & $\begin{array}{l}\text { - Äriidee esitamine } \\
\text { ja põhjendamine } \\
\text { võistlussituatsioonis }\end{array}$ & $\begin{array}{l}\text { - Äriideede } \\
\text { eelkonkursid ja } \\
\text { potentsiaalsete } \\
\text { probleemide analüüsid } \\
\text { ettevõtlusõppe raames }\end{array}$ \\
\hline $\begin{array}{l}\text { Investori-äriinglina } \\
\text { ettevõtluses tegutsejad, } \\
\text { ühisrahastusel } \\
\text { põhinevate ette- } \\
\text { võtlusprojektide } \\
\text { finantseerijad }\end{array}$ & $\begin{array}{l}\text { - Investeerimisobjektide } \\
\text { valik ja start-up-tiimide } \\
\text { hindamine }\end{array}$ & $\begin{array}{l}\text { - Potentsiaalsete } \\
\text { äriinglite ja } \\
\text { alustavate ettevõtjate } \\
\text { ühiskoolitused }\end{array}$ \\
\hline $\begin{array}{l}\text { Akadeemilised } \\
\text { ettevõtjad }\end{array}$ & $\begin{array}{l}\text { - Ülikoolide ja ettevõtjate } \\
\text { koostöö võimalused }\end{array}$ & $\begin{array}{l}\text { - SPINNO programmi } \\
\text { õppetunnid }\end{array}$ \\
\hline $\begin{array}{l}\text { Eetiliselt küsitava, } \\
\text { keskkonda, sotsiaalset } \\
\text { sidusust ja ettevõtlusest } \\
\text { mõjutatud inimeste } \\
\text { huve kahjustava } \\
\text { ettevõtluse ja vari- } \\
\text { majandusega kokku } \\
\text { puutunud õppijad }\end{array}$ & $\begin{array}{l}\text { - Ettevõtluse funktsioonid ja } \\
\text { disfunktsioonid ühiskonnas, } \\
\text { ettevõtluse kriitika } \\
\text { (eri haridusastmetel } \\
\text { käsitlemise sügavus) }\end{array}$ & $\begin{array}{l}\text { - Dispuut eri poliitiliste } \\
\text { liikumiste esindajate } \\
\text { osalusel }\end{array}$ \\
\hline
\end{tabular}




\title{
Entrepreneurship types and internationalization in entrepreneurship learning
}

\author{
Tiit Elenurm ${ }^{\text {al }}$ \\ ${ }^{a}$ Estonian Business School
}

\begin{abstract}
Summary
The Estonian Entrepreneurship Growth Strategy 2014-2020 sets the general goal of attaining $80 \%$ of the average EU productivity. This strategy identifies important target groups of emerging and fast-growing ambitious enterprises whose annual sales exceeds by the end of the second year of operation 200,000 euros and whose export intensity will be at least $25 \%$ of their sales turnover (Majandus- ja Kommunikatsiooniministeerium, 2013). In order to create in Estonia globally competitive business environment and efficient production of products and services with high added value for the benefit of the entrepreneurial population, ambitious enterprises and increased export opportunities, internationalization of entrepreneurship learning is needed. However, different target groups involved in entrepreneurship education have diversified experience, readiness to start their own locally or internationally oriented business or act as intrapreneurs in existing business organizations. Sector-specific learning by doing opportunities and the need to integrate entrepreneurship education with international business knowledge has to be also taken into consideration when applying entrepreneurship education as an entrepreneurship growth tool. This article aims to address an essential question for developing international entrepreneurship in a small open economy: What is the basis for differentiating entrepreneurship education for different target groups?

Literature review reflects research by Welter (2011) and other authors explaining the links between context variables and specific types of entrepreneurial initiatives. Zahra et al. (2014) have explained, how the features of business sectors, development stages of markets, temporal, social and spatial context has to be taken into consideration when developing entrepreneurs. Kuratko et al. (2015) have compared the process of creating a new venture and modes of intrapreneurship that can be supported, when developing entrepreneurial spirit inside existing organizations. Among departure points for differentiating entrepreneurship education is the entrepreneurial orientation concept (Lumpkin \& Dess, 1996; Lumpkin \& Lichtenstein, 2005). Elenurm and
\end{abstract}

Estonian Business School, A. Lauteri 3, 10114 Tallinn, Estonia; tiit.elenurm@ebs.ee 
Moisala (2008) have introduced a self-assessment questionnaire for specifying imitative, individually innovative and co-creative orientations in order to customize educational methods to support entrepreneurial journeys of target groups following these orientations.

Kwong and Thompson (2016) have pointed out the contradiction that although learning through practical entrepreneurship has been a key element of curriculum in many universities during recent decades, students focused on long-term innovative product development often prefer to learn from the experience of established entrepreneurs, create some financial basis and broaden their social network before starting their own business. Entrepreneurship education discourse has specified to some extent competing departure points of entrepreneurship education (O'Connor, 2013). Applying learning by doing through practical venture creation and business idea commercialization processes is a suitable framework if the student enterprise team is ready to jumpstart such a process and their sector-specific resource base can be created. Learning for future entrepreneurship by exploring features and role models of successful entrepreneurs in various countries, studying different types of entrepreneurship, including social entrepreneurship, and new business opportunities in emerging industries is however also operational for students that need to broaden their interdisciplinary knowledge base and create their international network before launching a real start-up initiative.

Global Entrepreneurship Monitor (GEM) 2012-2014 Estonian surveys have demonstrated that entrepreneurs with international growth ambitions and innovation focus often rely on knowledge sharing with people arriving from other countries while entrepreneurs that are domestically focused trust more their close friends and spouses as business knowledge sources (Venesaar et al., 2014a). Cross-border entrepreneurship assumes a broader network and more diversified knowledge source than locally oriented entrepreneurship. Crossborder entrepreneurship is not limited to export and import operations. It can be driven by cross-border licensing of new technologies and products, knowledge sharing in international teams of founders and investors.

Preparing students for involvement in different types of cross-border entrepreneurship assumes broadening their networking skills with potential entrepreneurs from other countries and learning through projects where international student teams assist start-up entrepreneurs in their internationalization efforts. Examples of educational practices that have been applied at the Estonian Business School to link entrepreneurship and international business competencies include Cross-border business projects for Baltic entrepreneurs, participation in X-Culture global project teams and in the Business opportunities in 
virtual networks cross-border course that links students in Tallinn and Helsinki to joint teams.

Based on analysis of earlier research and reflection of priorities of students involved in entrepreneurship learning, the following classification of target groups can be used for differentiating learning outcomes, content and methods of learning:

1. Level of education and learning outcomes of earlier specialization(s) as the input for entrepreneurship education.

2. Earlier work and entrepreneurship experience of learners.

3. Is the learner's priority independent entrepreneurship or intrapreneurship?

4. How are the learner's objectives linked to social and regional development?

5. Is the learner oriented to entrepreneurship in a co-creative team, to individual entrepreneurship or prefers to be self-employed?

6. Readiness of the learner to start and/or to develop a real enterprise during the entrepreneurship education programme.

7. Is the objective of the learner to develop a business model for a scalable start-up or step by step organic business growth?

8. Ambition of the learner to enter foreign markets and to develop international entrepreneurship.

9. Is the entrepreneurship education participant an Estonian resident or a non-resident who will potentially become connected to Estonia through entrepreneurship education and practical entrepreneurship?

During the special session of the annual conference of the Estonian Economic Association in 2016, 30 participants identified the highest priority target groups of entrepreneurship education for acceleration of the economic and social development in Estonia in the coming years. We applied group work where a tool explaining some optional learning methods that are relevant for different target groups was used. The following high priority target groups were specified by participants for differentiating entrepreneurship education in Estonia:

- Social entrepreneurs and hybrid entrepreneurs focused on linking social and economic goals;

- Start-up entrepreneurs that are internationally focused and have global business ambitions;

- Community (cooperative) entrepreneurs focused on utilizing local resources;

- Family business owners interested in handing owner business to their children (business continuity issues);

- Entrepreneurs commercializing R\&D results, academic entrepreneurs;

- Intrapreneurs; 
- Entrepreneurs in the digital sharing economy;

- Young people making a career change from the role of an employee to entrepreneurship but also people close to retirement age or retired people that have the same intention;

- Experts that lose their jobs as the result of structural changes in the Estonian economy.

Highlighting specific target groups does not exclude combination of different target groups as a source of knowledge sharing and synergy in training processes. The national entrepreneurship education system can take care of interdisciplinary connections between entrepreneurship and international business courses that are essential for entrepreneurs in export-oriented small open economies.

Entrepreneurship education in a small country has limited resources for global expansion but cross-border entrepreneurship learning module linked to a massive open online course can facilitate access of young Estonian entrepreneurs to new global business opportunities by broadening their online networks for tracing new cross-border business opportunities together with students in other countries. It is also a tool for using Estonian e-residency combined with Estonian entrepreneurship education to attract to Estonia larger numbers of talented foreign students that could bring new entrepreneurial ideas supporting knowledge-based economic growth.

Keywords: entrepreneurship education, entrepreneurship types, internationalization, innovation, networking 